This is the peer reviewed version of the following article: Bugeja Martin and Da Silva Rosa Raymond 2010, 'Capital gains taxation and shareholder wealth in takeovers', Blackwell Publishing Ltd, vol. 50, no. 2, pp. 241-262.. which has been published in final form at http://dx.doi.org/10.1111/j.1467-629X.2009.00334.x This article may be used for noncommercial purposes in accordance With Wiley Terms and Conditions for self-archiving' 


\title{
Capital gains taxation and shareholder wealth in takeovers
}

\author{
By \\ Martin Bugeja* \\ University of Technology, Sydney \\ and \\ Raymond da Silva Rosa \\ University of Western Australia, Business School
}

Current version: 30 September, 2009

Key Words: Capital gains taxation, mergers and acquisitions, method of payment JEL Classifications: H24, G32, G34

\footnotetext{
* Corresponding author: Martin Bugeja, School of Accounting, University of Technology, Sydney, PO Box 123, Broadway, 2007, New South Wales, Australia. Telephone + 6129514 3743, fax + 61295143669 .

E-mail address: martin.bugeja@uts.edu.au

Acknowledgements: The authors are appreciative of the research support provided by the Faculty of Economics and Business at the University of Sydney. We also acknowledge the helpful comments of Whitney Hudson, John Robinson, an anonymous referee and participants at the 2007 Australasian Finance and Banking Conference and the 2009 American Accounting Association Annual Meeting
} 


\title{
Capital gains taxation and shareholder wealth in takeovers
}

\begin{abstract}
Before December 1999, the capital gains of shareholders who sold their shares into Australian takeovers have been taxable irrespective of payment method. Subsequently, shareholders can elect to rollover capital gains in equity takeovers. We examine the effect of this change on the association between target shareholder capital gains and bidder and target firm shareholder wealth. The results indicate that prior to the regulatory change, cash consideration results in higher target shareholder returns for non-taxation reasons. After the introduction of capital gains tax rollover relief, we find that target and acquiring firm shareholders earn lower returns when cash consideration is offered to shareholders with greater capital gains.
\end{abstract}




\section{Introduction}

The impact of payment method on shareholder wealth has been well researched. The conclusion from these studies is that target firm shareholders receive higher abnormal returns around takeover announcements when cash is offered as payment (e.g. Wansley, Lane and Yang, 1983 and Da Silva Rosa, Izan, Steinback and Walter, 2000). For acquiring firm shareholders, prior studies generally find that cash bidders earn insignificant abnormal returns, whilst equity bidders have significant negative returns (e.g., Travlos, 1987; Bellamy and Lewin, 1992).

Although many reasons have been put forward for why premiums and returns of acquiring and target firms diverge across payment method, an explanation that has achieved prominence is the difference in taxation treatment across payment methods. In the United States and United Kingdom, shareholders are immediately liable for capital gains tax when they receive cash in exchange for disposing their shares as part of a takeover offer. In comparison, shareholders who receive equity have the ability to defer taxation to the time when they subsequently dispose of the acquiring firm shares. ${ }^{1}$ The basis of the taxation hypothesis is that the immediate taxable status where cash is used as payment results in target shareholders demanding a higher takeover premium relative to equity bids.

Directly related to the taxation hypothesis is the 'lock-in' effect associated with taxing capital gains at the realisation point as opposed to when they are accrued. Taxing

\footnotetext{
${ }^{1}$ The HM Revenue and Customs Help Sheet IR285: "Share Reorganisations, company take-overs and capital gains tax" available at: http://www.hmrc.gov.uk/pdfs/1998 99/helpsheets/ir285.pdf provides a description of the U.K. taxation treatment of target shareholders. The U.S. position is legislated in Section 368 of the Internal Revenue Code.
} 
capital gains only when realised acts as a disincentive for shareholders to dispose of shares that have appreciated in value. In the context of a takeover, target shareholders with a higher unrealised taxable capital will expect a higher premium to compensate them for realising their capital gain. However, as indicated by Ayers, Lefanowicz and Robinson (2003), testing this expectation is confounded by the asymmetric tax treatment of capital gains tax across payment consideration.

In contrast to the taxation arrangements in the U.S. and U.K., before 10 December 1999, Australian shareholders have been liable for capital gains tax on the sale of their shares into a takeover irrespective of the type of payment received. This symmetry in taxation treatment across payment method allows us to directly test for an association between target shareholder capital gains and premiums, whilst avoiding the problem identified in Ayers, Lefanowicz and Robinson (2003).

From 10 December 1999, shareholders that receive equity in an Australian takeover may elect to defer taxation until the subsequent sale of the shares received as consideration. Bugeja and Da Silva Rosa (2008) present evidence showing that, subsequent to this regulatory change, bidding firms offered cash less frequently to target firms whose shareholders had larger capital gains. This study extends that research to examine if the change in Australian taxation treatment of capital gains impacted on target and acquiring firm abnormal returns around takeover announcements. Our findings further extend prior research by providing additional evidence on the importance (or otherwise) of taxation in explaining shareholder wealth effects arising around the announcement of a takeover. 
We find that cash payment is associated with higher target shareholder abnormal returns during the timeframe when there are no differences in taxation across payment method. This finding indicates that the explanation for cash payment increasing target abnormal returns is not driven by taxation. Consistent with the taxation hypothesis, we find that, after the change in taxation, target shareholders with higher capital gains earn lower abnormal returns when they are offered taxable consideration (i.e., cash). The results for acquiring firms indicate no relationship between payment form and abnormal returns. Similar to the target firm results, bidding firm abnormal returns are lower when cash is offered as consideration to target shareholders with higher capital gains.

The remainder of this study is structured as follows. The next section outlines the Australian taxation treatment of shareholders and describes previous research relevant to this study. Section 3 discusses the models tested in the paper, whilst Section 4 describes the sample and presents results. The final section of the paper concludes and suggests areas for future research.

\section{Regulation and prior research}

\subsection{Taxation of shareholders in Australia}

In Australia, the disposal of shares acquired after 19 September 1985 results in a shareholder generating a taxable capital gain or loss under Section 104-10 of the Income Tax Assessment Act (ITAA). ${ }^{2}$ For shares disposed on or before 21 September 1999, shareholders can index the share’s cost for inflation when calculating the capital gain provided that the shares were owned for at least 12 months

\footnotetext{
${ }^{2}$ See http://law.ato.gov.au/atolaw/index.htm for a copy of the Income Tax Assessment Act (1997).
} 
(Section 114-1 of ITAA). For shares acquired after 21 September 1999, indexation of the cost is no longer available; however, individual shareholders can reduce the capital gain by $50 \%$ if the shares at the time of disposal had been held for longer than 12 months (Section 115-100 of ITAA). In the case that shares were acquired prior to 21 September 1999 and sold after this date, the shareholders were able to choose between the $50 \%$ capital gains tax discount and indexation of the purchase price on the proviso that the shares were owned for at least 12 months. $^{3}$

Prior to 10 December 1999, shares disposed under a takeover offer resulted in the shareholder realising a taxable capital gain or loss irrespective of the form of consideration received. From 10 December 1999 onwards, where there is an exchange of the same type of interest ${ }^{4}$ arising from a takeover; shareholders have the right to elect to rollover the capital gain until the ultimate disposal of the interest received in the exchange. Shareholders can only make such an election where the bidder, as a result of the takeover, obtains at least $80 \%$ ownership of the target (Sections 124-780 and 124-781 of ITAA). If target firm shareholders are offered both cash and equity, investors can only partially rollover the capital gain. ${ }^{5}$ This change in taxation regulation was introduced after extensive lobbying of the Australian federal government and resulted in the government concluding that the previous taxation arrangements "were considered an impediment to corporate acquisition activity in Australia.”6

\footnotetext{
${ }^{3}$ A summary of these requirements can be found at: http://www.ato.gov.au/businesses/content.asp?doc=/content/18427.htm

${ }^{4}$ This requires an exchange of equivalent interests. For example, shares need to be exchanged for shares or a trust interest needs to be exchanged for another trust interest.

${ }^{5}$ The original cost of the shareholding needs to be apportioned to work out the taxable capital gain that relates to the cash component of the consideration.

6 “Capital gains tax: scrip for scrip roll-over - questions and answers” - http://www.ato.gov.au/print. asp?doc=/content/18438.htm.
} 
Bugeja and Da Silva Rosa (2008) examine whether the introduction of capital gains tax rollover for target shareholders in Australian equity takeovers influenced the choice of payment method made by acquirers. Their results showed an increased frequency of bidding firms offering equity consideration when target shareholders had higher capital gains. This finding added to the results of previous research in the United States that had provided either limited support (Ayers, Lefanowicz, and Robinson, 2004) or no evidence (Erickson, 1998) that target shareholder capital gains influenced the method of payment choice of acquiring firms in takeovers.

\subsection{Method of payment and abnormal returns}

The impact of payment method on target and bidder firm shareholder wealth around takeover announcements has been extensively investigated. Studies from the United States, United Kingdom and Canada indicate that target firm shareholders earn significantly higher abnormal returns when cash is offered as payment (e.g., Wansley, Lane and Yang, 1983; Huang and Walkling, 1987; Franks, Harris and Mayer, 1988; Franks, Harris and Titman, 1991; Masse, Hanrahan and Kushner, 1991; Draper and Paudyal, 1999). Consistent Australian evidence is provided in Da Silva Rosa, Izan, Steinback and Walter (2000) and Bugeja (2005).

For acquiring firms, Travlos (1987) finds that cash bidders in the United States earn insignificant CARs over the three days centred on the takeover announcement. The results for equity bidders however are significantly negative. Similar results are reported by Amihud, Lev and Travlos (1990) and Franks, Harris and Titman (1991). The Australian evidence provided in Bellamy and Lewin (1992) shows that cash bidders earn insignificant returns on the announcement day, compared to significant negative returns for bidders that 
offer equity. Da Silva Rosa, Izan, Steinback and Walter (2000) report similar results, however, the difference between announcement returns for cash and equity bidders is insignificant.

The differential tax treatment across payment forms has been proposed as the main reason for why target and bidder returns differ across cash and equity offers. In the United States, where the acquisition is financed through at least $50 \%$ equity, the transaction is "nontaxable.” As a result, target shareholders can defer capital gains tax until the shares are subsequently sold. In contrast, cash offers are considered "taxable” transactions with target shareholders realising a capital gain or loss at the time of the sale. As a result of this immediate tax liability, Davidson and Cheng (1997) argue that target shareholders require the bidder in a cash offer to compensate them through the payment of a higher premium. Using U.S. data from 1981 to 1987, they find that, after controlling for the size of the bid premium, the form of payment is unrelated to target abnormal returns. Thus, they, conclude that the link between the payment method and the size of abnormal returns is indirect, cash bids must be greater to compensate for the immediate tax liability shareholders incur.

The 'lock-in’ effect of taxing capital gains taxes at the realisation point provides a disincentive to shareholders to sell appreciated shares and realise such gains (Klein, 1999 and Viard 2000). Ayers, Lefanowicz and Robinson (2003) argue that in a takeover a bidding firm must compensate target shareholders for removing their option to continue to defer any capital gains tax. As capital gains tax exposure differs across shareholders, the required takeover premium will be that which is required by the marginal price-setting shareholder. As the capital gains tax liability of the marginal shareholder increases, a bidder is required to pay a higher premium. Ayers, Lefanowicz and Robinson (2003), 
therefore, predict a positive relationship between takeover premiums and target shareholder capital gains. They test this prediction using U.S. data and report a positive relationship between premiums and target shareholder capital gains with the association decreasing in tax-free acquisitions and takeovers with higher target institutional ownership. Additionally, even after controlling for target shareholder capital gains, premiums are found to be lower in tax-free acquisitions.

Owing to the unavailability of individual shareholder data, studies (including the current study) investigating the association between target shareholder capital gains and takeover premiums are limited to using proxies for target shareholder gains on an average basis and cannot assess the impact of the marginal shareholder. One study not subject to this limitation is Landsman and Shackelford (1995). Using confidential shareholder data taken from the RJR Nabisco leveraged buyout in 1989, they show that shareholders with higher capital gains deferred their selling decision until there was an increase in the price of RJR Nabisco shares.

Considering that prior to December 1999, shareholders in Australia were required to pay CGT on shares disposed into a takeover irrespective of payment method, it is possible to test for a 'lock-in' effect of capital gains on target firm abnormal returns that is not confounded by the difference in taxation treatments across payment method described by Ayers, Lefanowicz and Robinson (2003). Furthermore, before December 1999, any association between method of payment and the abnormal returns received by acquiring and target firms cannot be explained by the taxation of target shareholder capital gains. We can, therefore, test if the association between method of payment and abnormal returns in takeovers is driven by reasons other than taxation. 
The modification to target shareholder taxation from December 1999 is used in this study to determine the influence of target shareholder capital gains taxes on abnormal returns. Evidence of an adjustment in abnormal returns after the introduction of CGT rollover relief would provide direct support to the taxation hypothesis. Subsequent to the change in regulation, target shareholders with high levels of unrealised capital gains will prefer equity consideration as this allows them to defer their capital gains tax payment. We, therefore, predict that subsequent to December 1999, target shareholders with higher capital gains will experience lower abnormal returns when offered cash consideration as their after tax capital gain will have a lower present value than for similar targets offered equity.

The effect of the regulatory change on bidding firm abnormal returns is unclear. Confronted with a certain level of target shareholder capital gains, the acquiring firm has a choice of offering cash, equity or a mix of cash or equity. The evidence in Bugeja and Da Silva Rosa (2008) indicates the likelihood of a cash takeover decrease as target shareholder capital gains increase. Following on from this finding, acquirers that offer cash to target shareholders with a higher capital gain are more likely to face hostility from the target firm and/or its shareholders due to the lower after tax return. If this creates an expectation of an increased offer, then acquiring firm abnormal returns are predicted to decrease at higher levels of target shareholder capital gains. Similarly, a cash bid to shareholders with larger capital gains may be viewed as having a higher probability of failure. In this case, the acquiring firm's announcement reaction will then depend on the market's assessment of whether the takeover was a profitable investment for the acquiring firm. 


\section{Model development and variable description}

This section describes the models used to investigate the impact of target shareholder capital gains and consideration type on acquiring and target firm abnormal returns. The first model we test uses takeovers announced prior to December 1999 and assesses if target shareholder capital gains and method of payment influence shareholder returns prior to the introduction of CGT rollover relief. The second model is designed to examine if these relationships were altered after the change in taxation arrangements in December 1999 and uses takeovers from before and after the regulatory change.

Acquiring (Bharbid) and target firm (Bhartgt) abnormal returns are measured by calculating the buy-and-hold abnormal return over the two month period commencing one month prior to the takeover announcement. The All Ordinaries Accumulation Index is used as the reference market return. As many of the independent variables are common to both models, the variables are described for both models simultaneously. Our discussion of the independent variables has been grouped as follows: taxation-related, target firm-related and takeover offer characteristics.

\subsection{Taxation determinants}

As capital gains are unique to each shareholder, it is necessary to use a proxy for target shareholder capital gains. For the first proxy, the estimated capital gain liability is calculated as the target firm share price 20 days before the takeover announcement less the average share price over the previous two years. This amount is then multiplied by the highest individual taxation rate and then divided by the average share price over the two years before the takeover announcement (CGPRIOR). The 
second measure employed (CGINDEX) assumes that the price-setting shareholder purchased their investment two years prior to the takeover announcement. For takeovers announced on or before 21 September 1999, this assumed purchase price is indexed for inflation and then subtracted from the target firm share price 20 days before the takeover announcement to calculate the capital gain. ${ }^{7}$ For takeovers announced after 21 September 1999, indexation is no longer available so the capital gain is measured as the price twenty days before the announcement less the price two years previous discounted by $50 \% .^{8}$ These calculated capital gains are then multiplied by the highest individual marginal tax rate and then divided by the share price two years before the takeover announcement. Across our study period, there was no change in the highest marginal tax rate levied on individuals.

The form of consideration offered is identified using an indicator variable denoting pure cash takeovers (Payt). Prior to December 1999, any relationship between payment form and abnormal returns will be unrelated to taxation. ${ }^{9}$ Non-taxation explanations for an impact of payment method choice include the information signalling role of consideration type in the presence of asymmetric information between managers and shareholders as described by Myers and Majluf (1983). Under this model, the use of equity consideration provides a signal that acquiring firm management believes their firm is over-valued.

To highlight any interaction between capital gains and payment form, we interact Payt respectively with the two measures of capital gains (CG*Payt). For model (2),

\footnotetext{
${ }^{7}$ No indexation is applied where there is a calculated capital loss.

${ }^{8}$ Where a capital loss is calculated, we do not apply the $50 \%$ capital gains discount.

${ }^{9}$ There may be an indirect tax consequence if target shareholders receiving equity need to sell the shares received to pay their capital gains tax liability.
} 
we include an additional interaction (CG*Payt*Change) to denote takeovers announced after the introduction of capital gains tax rollover relief. This variable should identify any change in target and acquiring firm abnormal returns arising from target shareholders with higher capital gains being offered consideration that is immediately taxable.

To capture any difference in abnormal returns arising simply because of the change in legislation, we include in model (2) a dummy variable (Change) indicating takeovers announced after 10 December 1999. This variable is also interacted alternately with the two measures of capital gains (CG*CHANGE) to highlight any change in the effect of capital gains arising after the introduction of CGT rollover relief that is unrelated to payment method.

Institutional investors include: corporations, superannuation funds and managed investment funds. As these investors are taxable at lower rates than individual investors, any relationship between capital gains and abnormal returns may decline with the level of target institutional ownership. This expectation is investigated by including an interaction variable between each respective capital gain proxy and institutional ownership (CG*TgtInst). Target institutional ownership is estimated from the Top 20 shareholder list released at the financial year end prior to the takeover announcement. ${ }^{10}$ We also include institutional ownership (TgtInst) itself as an additional variable to identify any effect that is unrelated to capital gains.

\footnotetext{
${ }^{10}$ Similar to Henry (2005), we define institutional shareholders as: life and non-life insurance companies, fund management companies, banks, superannuation funds and investment companies. Nominee shareholdings are not included unless it is indicated that they are institutional accounts.
} 
Ayers, Lefanowicz and Robinson (2003) find that takeover premiums are positively related to the target firm net operating loss carry forward. In Australia, firms can only apply prior year losses against current taxable income if they satisfy the "same business" or "continuity of ownership” tests (section 165-5 of ITAA). The continuity of ownership test requires that more than $50 \%$ of voting, dividend and capital rights be owned by the same shareholders from the start of the financial year the tax loss was incurred to the end of the financial year that the loss is to be offset against taxable income. The same business test requires that the entity be carrying on the same business in the claim year as it was at the start of the loss year. Carry forward losses are collected from the financial statements of the target firm for the financial year end prior to the takeover announcement. The amount of the carry forward tax loss is multiplied by the applicable corporate tax rate and divided by the market value of equity at financial year end $(N O L)$.

\subsection{Target and acquiring firm characteristics}

Stulz (1988) argues that target firm ownership structure is a determinant of takeover premiums. Where the acquiring firm must obtain acceptance from a greater number of external shareholders, a higher premium must be offered. Supporting this argument, Stulz, Walkling and Song (1990) show target abnormal returns in the United States are positively associated to the ownership of target firm managers and negatively related to the bidder's toehold. Similar results for the bidder's toehold are found in Australia (Bugeja and Walter, 1995). To control for target ownership structure, the acquiring firm toehold (Toehold) and the ownership of target firm directors (TgtDirown) at the time of the takeover announcement are added to the models. 
Following Comment and Schwert (1995) and Schwert (2000), a number of target firm financial characteristics are included in the analysis of shareholder returns. These financial characteristics are designed to capture dimensions of target firm performance and risk. Target firm performance is measured using the market-to-book ratio (TgtMB) and return-on-equity ratio (TgtROE), whilst risk and liquidity are proxied using respectively the debt-to-equity (TgtDE) and current ratio (TgtCurrent). Each ratio is measured at the financial year end prior to the takeover announcement.

Moeller, Schlingemann and Stulz (2004) examine the returns to acquiring firm shareholders in US acquisitions. They show that announcement returns are significantly higher for small bidding firms. We include the natural logarithm of acquiring firm market capitalisation in our regression models to control for firm size (Bidsize). Market capitalisation is measured as at the financial year end preceding the takeover announcement.

\subsection{Takeover offer characteristics}

Although it is hypothesised that target and acquiring firm shareholder wealth will be related to target firm hostility, prior research results are varied. Studies in the United States (Cotter and Zenner, 1994) and Australia (Henry 2005 and Bugeja 2005) fail to document an association between hostility and abnormal returns. In contrast, results in the United Kingdom show significantly higher premiums in hostile takeovers (Franks and Mayer, 1996). Target firm hostility is controlled by including a binary variable in the models signifying takeovers where the initial recommendation of the target board is to recommend acceptance (Dirrec). 
The presence of competing bidders is expected to increase/(decrease) target/(bidder)firm abnormal returns. The presence of multiple bidders is identified in the models using a dummy variable coded as one, where more the one bidder make a simultaneous offer for the target firm (Multiple).

In summary, the model estimated for takeovers announced before December 1999 is:

BHAR $_{i}=\alpha_{i}+\beta_{1} \mathrm{CG}_{\mathrm{i}}+\beta_{2}$ Payt $_{\mathrm{i}}+\beta_{3} \mathrm{CG}_{\mathrm{i}} *$ Payt $_{\mathrm{i}}+\beta_{4}$ TgtInst $_{\mathrm{i}}+\beta_{5} \mathrm{CG}_{\mathrm{i}} *$ TgtInst $_{\mathrm{i}}+\beta_{6} \mathrm{NOL}_{\mathrm{i}}$ $+\beta_{7}$ Toehold $_{i}+\beta_{8}$ TgtDirown $_{i}+\beta_{9}$ TgtMB $_{i}+\beta_{10}$ TgtROE $_{i}+\beta_{11}$ TgtDE $_{i}+$ $\beta_{12}$ TgtCurrent $_{\mathrm{i}}+\beta_{13}$ Multiple $_{\mathrm{i}}+\beta_{14}$ Dirrec $_{\mathrm{i}}+\beta_{15}$ Bidsize $_{\mathrm{i}}+\varepsilon_{\mathrm{i}}$

To assess any changes arising from the introduction of capital gains tax rollover relief for equity consideration, we estimate the following model for takeovers pre and post December 1999:

$$
\begin{aligned}
& \text { BHAR }_{i}=\alpha_{i}+\beta_{1} \text { CG }_{i}+\beta_{2} \text { Payt }_{i}+\beta_{3} \text { CG }_{i} * \text { Payt }_{i}+\beta_{4} \text { CG }_{i} * \text { Payt }_{i}^{*} \text { Change }_{i}+ \\
& \beta_{5} \text { CG }_{i} * \text { Change }_{i}+\beta_{6} \text { Change }_{i}+\beta_{7} \text { TgtInst }_{i}+\beta_{8} \text { CG }_{i} * \text { TgtInst }_{i}+\beta_{9} \text { NOL }_{i}+\beta_{10} \text { Toehold }_{i}+ \\
& \beta_{11} \text { TgtDirown }_{i}+\beta_{12} \text { TgtMB }_{i}+\beta_{13} \text { TgtROE }_{i}+\beta_{14} \text { TgtDE }_{i}+\beta_{15} \text { TgtCurrent }_{i}+ \\
& \beta_{16} \text { Multiple }_{i}+\beta_{17} \text { Dirrec }_{i}+\beta_{18} \text { Bidsize }_{i}+\varepsilon_{i}
\end{aligned}
$$

Both models are estimated separately using respectively target and acquiring firm BHARs. Further, the testing for both bidder and target firms is conducted separately for each proxy of target shareholder capital gains. 


\section{Data and results}

Takeovers announced to the ASX for publicly listed firms during the time period 1996 to 2003 were identified using the Connect 4 Mergers and Acquisitions Database. This period includes approximately four years before and after the tax regime change. A number of sources were used to collect data required to estimate the regression models. Annual reports for target firms in the year preceding the takeover were used to hand collect accounting information and institutional ownership. Takeover documents lodged with the ASX were used to collect information on method of payment, ownership of target firm directors and other takeover characteristics. ${ }^{11}$ The Connect 4 Mergers and Acquisitions Database and the Securities Industry Research Centre of Asia-Pacific's (i.e., SIRCA) TIFF Images of ASX announcements were used as the source of takeover documents. Share price data needed to calculate BHARs and takeover premiums was collected from the Core Research Database maintained by SIRCA. Abnormal returns are calculated by subtracting the return on the All Ordinaries Accumulation Index from sample firm returns.

Takeovers were excluded to ensure a complete data set was available to estimate the regression models. The final sample size is 205 takeovers. The reasons for exclusion of observations are summarised in Table $1 .^{12}$

\section{INSERT TABLE 1 HERE}

\footnotetext{
${ }^{11}$ These other items include: the recommendation of the target firm board, the toehold interest of the acquiring firm and the presence of competing bidders.

${ }^{12}$ The sample in this paper is marginally greater than that used in Bugeja and Da Silva Rosa (2008). The main explanation for this difference is the regression models used in this study make less use of bidding firm variables. As such, we were not required to exclude as many takeovers due to missing data for the bidder.
} 
Table 2 provides summary statistics on target and acquiring firm BHARs and the two measures of capital gains. Panel A and B respectively present information before and after the introduction of CGT rollover relief. Within each panel, the data is partitioned across consideration type. As expected, target shareholders earn significant BHARs around takeover announcements. On the other hand, acquiring firm BHARs are generally negative and are only significantly different from zero for mixed consideration bids prior to December 1999 and equity takeovers after the introduction of the CGT rollover relief. A comparison of mean BHARs before and after the change in taxation for individual payment types reveals no statistical differences. On an overall basis, however, target BHARs are significantly greater after the revision in taxation.

\section{INSERT TABLE 2 HERE}

For the whole sample, both capital gains measures are negative both before and after the tax change. A $t$-test shows that target shareholder capital gains are significantly lower before the change in taxation treatment using the CGPrior variable. Across alternative payment methods, average target shareholder gains are generally insignificantly different from zero (other than for equity bids).

Descriptive statistics on the variables included in the regression models are provided in Table 3. Consistent with earlier research, target firm abnormal returns are significantly higher in cash bids relative to equity takeovers. Both measures of capital gains indicate that cash takeovers are associated with significantly greater capital gains than equity bids. Target firms appear to be unprofitable with mean return on 
equity being $-9.93 \%$. Target institutional and director ownership are respectively 10.89\% and 11.33\%. Consistent with the findings in Bugeja and Da Silva Rosa (2008), equity is used as payment in takeovers when the acquiring firm toehold is lower. This is likely explained by the higher amount of cash required with a lower initial shareholding. Acquiring firms offering equity consideration are significantly smaller than those offering cash or mixed payment forms.

\section{INSERT TABLE 3 HERE}

Table 4 presents the results of estimating the regression models using BHARTgt as the dependent variable. White’s (1980) consistent covariance estimator is used for all reported $t$-statistics. Inconsistent with a 'lock-in' effect,' there is no evidence of an association between target shareholder capital gains and abnormal returns either preceding or subsequent to the change in taxation requirements. The results indicate that the use of cash payment is associated with significantly higher abnormal returns. The significant result prior to December 1990 is explained by non-taxation reasons as there was symmetry in the taxation of capital gains across consideration forms during this time period. As the coefficients on $C G^{*}$ Payt are insignificant, returns to shareholders offered cash are not affected by the size of their capital gains. However, the interaction of this variable with CHANGE provides significant negative coefficients in the period after December 1999. This result indicates that although target shareholders earn higher returns in cash takeovers, after the introduction of CGT rollover relief where shareholders offered cash face a higher capital gains liability their return is lower due to the requirement to pay immediate taxation. 
Of the control variables, Dirrec has a significant negative coefficient over the full sample period indicating that target abnormal returns are higher in hostile takeovers. One potential explanation is that an accept recommendation lowers the probability of a price increase by the bidder (Bugeja, 2005). The significant coefficient on Change indicates that target returns are higher after the change in taxation arrangements consistent with the univariate findings. Target directors' ownership is significant in two of the columns. The negative coefficient, however, is inconsistent with expectations. Of the target firm financial characteristics, TgtMB and TgtROE are negatively associated with abnormal returns, whilst TgtDE has a positive effect. The negative coefficient on the market-to-book ratio is consistent with bidders offering a lower premium when the value of the target represents growth options as the potential for overpayment is higher in these circumstances. The positive relationship between target shareholder wealth and target firm leverage is consistent with the models in Israel (1991) and Israel (1992) and the results in Raad, Ryan and Sinkey (1999). Target liquidity and acquiring firm size have no impact on target firm abnormal returns.

\section{INSERT TABLE 4 HERE}

The impact of target shareholder capital gains on acquiring firm shareholder wealth is shown in Table 5. Once more, $t$-statistics are based on White’s (1980) consistent covariance estimator. The results indicate no association between abnormal returns and either target shareholder capital gains or payment method. However, subsequent to the introduction of the CGT rollover relief acquiring firm shareholders experience lower returns when cash is offered to target shareholders with a higher capital gain. 
This outcome may be the result of offering target shareholders with greater capital gains taxable consideration leading to the expected of greater hostility from the target firm. Greater hostility would potentially lead to either to an increased offer price or an unsuccessful takeover. To test if this is the case, we estimated logit models with alternately takeover outcome, target board recommendation and an increase in the offer price as the dependent variable. The independent variables are identical to those used in model (2). ${ }^{13}$ The coefficient on $C G^{*}$ Payt*Change was insignificant in all models (results not reported) indicating that any perception that offering taxable consideration to shareholders with higher capital gains would result in a protracted hostile takeover contest is unwarranted.

\section{INSERT TABLE 5 HERE}

Acquiring firm returns are associated with some of the controls for target firm financial characteristics with TgtMB negatively related to acquiring firm BHARs. An explanation for this result is that acquiring firms are more likely to overpay for high growth targets. Model (2) shows a significant positive effect of target leverage, whilst target liquidity has a significant negative coefficient using both models. TgtROE and acquiring firm size are unrelated to acquiring firm abnormal returns. The insignificant findings for acquiring firm size stand in contrast to the results in Moeller, Schlingemann and Stulz (2004). Target institutional ownership and target carryforward losses are both positively related to acquiring firm abnormal returns for model (2). The number of bidders, the recommendation of the target firm board and target directors’ ownership do not influence acquiring firm returns.

\footnotetext{
${ }^{13}$ In the model of target board recommendation, Dirrec was excluded as an independent variable.
} 


\subsection{Additional analysis}

In our analysis of acquiring and target shareholder abnormal returns, we assume in the calculation of capital gains that target shareholders have held their shares for two years. To assess the impact of this assumption, we calculate the average holding period for each target firm by dividing the number of issued shares at the date of the takeover announcement by the average daily trading volume over the prior two years. We then re-estimate our results using only those targets where the calculated holding period is less than 3 years (approximately $75 \%$ of the sample). The conclusions drawn from these revised results do not differ from those presented.

Until September 1999, shareholders who had owned their shares for at least 12 months indexed the cost of their investment for inflation when calculating capital gains. On September $19^{\text {th }}, 1999$ the indexation system was removed and was replaced by a 50\% capital gains discount for shareholders owning their shares for a minimum of 12 months. Since this change occurred only three months prior to the introduction of the CGT rollover relief in equity takeovers, it is possible that the results presented above are actually driven by the introduction of the 50\% discount. Furthermore, after September 1999, shareholders holding appreciated shares for less than 12 months would be despondent to receive a cash takeover as they were only a short time period away from halving their liability. Assuming these short term shareholders are the marginal investors in cash takeovers they would demand a higher premium to compensate them for the loss of the capital gains discount. ${ }^{14}$ The impact of the introduction of the $50 \%$ discounting of capital gains is investigated by Hanlon and Pinder (2007) in the context of initial public offerings. They find evidence of an

\footnotetext{
${ }^{14}$ We are grateful to an anonymous referee for pointing out the possible confounding influencing arising from the move from the indexation regime to a capital gains discount.
} 
increase in abnormal trading volume immediately subsequent to the 12 month listing anniversary for shares that had appreciated by a greater amount since listing. This result is consistent with investors having higher unrealised capital gains waiting to trade until after the 12 month qualification period was met to take advantage of the capital gains discount.

To assess if our results are driven by investors with holding periods of less than 12 months, we change the measure of our two capital gains proxies to a one year measure. The first proxy is re-measured as the target firm share price 20 days before the takeover announcement less the average price over the prior 12 months. This amount is then multiplied by the highest individual taxation rate and then divided by the average share price over the one year period (CGPRIOR1yr). The second measure employed (CGINDEX1yr) assumes that the price-setting shareholder purchased their holding one year prior to the takeover announcement. This price is subtracted from the share price 20 days prior to the takeover announcement and the resulting capital gain is then multiplied by the highest individual marginal tax rate. This amount is then divided by the share price one year before the takeover announcement. We then re-estimate model (1) and (2) using alternately each of the re-measured capital gain variables. In the alternative specification of model (2), we re-define the CHANGE variable to be the date of change to the indexation system as opposed to the introduction of the CGT rollover relief (CHANGEIDX). These results are presented in Table 6 for target abnormal returns. ${ }^{15}$

\section{INSERT TABLE 6 HERE}

\footnotetext{
${ }^{15}$ The mean values of CGPRIOR 1yr and CGINDEX1yr were respectively $-0.96 \%$ and $2.46 \%$.
} 
The results on both measures of capital gains continue to be insignificant both over the entire sample period and the period preceding the introduction of the capital gains' discount. Furthermore, the coefficient on the interaction between: payment method, capital gains and the introduction of the $50 \%$ discount of capital gains, is insignificant. Overall, the results are, therefore, consistent with the introduction of the CGT rollover relief changing the association between takeover premiums and capital gains and payment method as opposed to the introduction of the $50 \%$ capital gains discount. This result is perhaps expected as an investigation of the estimated holding period of target firm shareholders indicates that only six target firms have a calculated holding period of less than one year. As such, only a small proportion of target firms have shareholders that on average have held their shares for less than 12 months. The results shown in Table 6 for the control variables are mainly consistent with those shown in Table 4. The main difference is that return on equity is insignificant in each of the model variations.

We also re-estimated the results for bidding firm abnormal returns using our one year capital gain measures and the re-defined change variable. The results (not presented) were broadly consistent with those in Table 5 . The main difference, however, is that the interaction between capital gains, payment method and the change to indexation was insignificant. Thus, similar to the results for target firms, the important taxation change was the introduction of the capital gains rollover relief in equity takeovers as opposed to the change to the indexation system. 


\section{Conclusions and future research}

Dissimilar taxation treatment on the disposal of shares in takeovers across consideration types has commonly been proposed as explaining differences in target shareholder abnormal returns. Prior to December 1999, target shareholders in Australia were taxable on capital gains irrespective of payment method, thereby enabling us to conduct a direct test of the influence of taxation and method of payment choice on shareholder wealth. Inconsistent with a 'lock-in' effect, our results show no association between target shareholder capital gains and target shareholder abnormal returns. Additionally, we find that cash payment is associated with higher target shareholder abnormal returns before the change in taxation. Considering that during this timeframe shareholder gains are taxable irrespective of the type of consideration, this finding indicates that cash payment increases target shareholder returns for non-taxation reasons. An investigation of these alternative reasons would be a fruitful area for future research.

From December 1999, target shareholders can elect to rollover capital gains when they receive equity consideration as part of a takeover. Our results indicate that, after this regulatory change, target shareholders with higher capital gains received lower abnormal returns when offered cash consideration. This result is consistent with the after tax return for these shareholders being lower than that for equivalent shareholders offered equity. This finding highlights the influence of shareholder taxation on target shareholder wealth in takeovers.

For acquiring firms we find no association between payment method or target shareholder capital gains and abnormal returns. Consistent with the target firm 
results, we document that, after the introduction of the CGT rollover relief, acquiring firm abnormal returns are significantly lower when acquiring firms offer immediately taxable consideration to target shareholders with higher levels of capital gains. Potential explanations for this finding include a perception that such takeovers will lead to greater resistance from the target firm board and in consequence result in a protracted takeover battle with possible offer price increases.

Similar to most studies investigating the influence of shareholder level capital gains taxes, it is not possible to obtain data to allow us to calculate capital gains liabilities for individual shareholders. As such, we are limited to estimating capital gains taxes for the average shareholder, as opposed to the marginal shareholder. These limitations must be considered when assessing the findings of this study. 


\section{References}

Amihud, Y., B. Lev, and N. Travlos, 1990, Corporate control and the choice of investment financing: the case of corporate acquisitions, Journal of Finance 45, 603616.

Ayers, B., C. Lefanowicz, and J. Robinson, 2003, Shareholder taxes in acquisition premiums: The effect of capital gains taxation, Journal of Finance 58, 2783-2801. Ayers, B. C. Lefanowicz, and J. Robinson, 2004, The effect of shareholder-level capital gains taxes on acquisition structure, Accounting Review, 79, 859-887. Bellamy, D., and W. Lewin, 1992, Corporate takeovers, method of payment, and bidding firms’ shareholder returns: Australian evidence, Asia Pacific Journal of Management 9, 137-149.

Bugeja, M., 2005, The effect of independent expert reports in Australian takeovers, Accounting and Finance 45, 519-536.

Bugeja, M., and R. Da Silva Rosa, 2008, Taxation of target shareholder capital gains and the choice of payment method in takeovers, Accounting and Business Research 38, 331-350.

Bugeja, M., and T. Walter, 1995, An empirical analysis of some determinants of the target shareholder premium in takeovers, Accounting and Finance 35, 33-60.

Comment, R., and G. Schwert, 1995, Poison or placebo? Evidence on the deterrence and wealth effects of modern antitakeover measures, Journal of Financial Economics 39, 3-43.

Cotter, J., and M. Zenner, 1994, How managerial wealth affects the tender offer process, Journal of Financial Economics 35, 63-97. 
Da Silva Rosa, R., H. Izan, A. Steinback, and T. Walter, 2000, The method of payment decision in Australian takeovers: An investigation of causes and consequences, Australian Journal of Management 25, 67-94.

Davidson, W., and L. Cheng, 1997, Target firm returns: does the form of payment affect abnormal returns? Journal of Business, Finance and Accounting 24, 465-479. Draper, P., and K. Paudyal, 1999, Corporate takeovers: Mode of payment, returns and trading activity, Journal of Business, Finance and Accounting 26, 521-558.

Erickson, M., 1998, The effect of taxes on the structure of corporate acquisitions, Journal of Accounting Research 36, 279-298.

Fishman, M., 1989, Preemptive bidding and the role of the medium of exchange in acquisitions, Journal of Finance 44, 41-57.

Franks, J., R. Harris, and C. Mayer, 1988, Means of payment in takeovers: Results in the United Kingdom and the United States, in: AJ Auerbach (ed.), Corporate Takeovers: Causes and Consequences, (University of Chicago Press, Chicago), 221264.

Franks, J., R. Harris, and S. Titman, 1991, The postmerger share-price performance of acquiring firms, Journal of Financial Economics 29, 81-96.

Franks, J., and C. Mayer, 1996, Hostile takeovers and the correction of managerial failure, Journal of Financial Economics 40, 163-181.

Hanlon, D., and S. Pinder, 2007, An empirical investigation of whether Australian capital gains tax reforms influence individual investor behaviour, Pacific Basin Finance Journal 15, 481-493.

Henry, D., 2005, Directors' Recommendations in takeovers: An agency and governance analysis, Journal of Business, Finance and Accounting 32, 129-159. 
Huang, Y., and R. Walkling, 1987, Target abnormal returns associated with acquisition announcements: Payment acquisition form, and managerial resistance, Journal of Financial Economics 19, 329-349.

Israel, R., 1991, Capital structure and the market for corporate control: The defensive role of debt financing. Journal of Finance 46, 1391-1409.

Israel, R., 1992. Capital and ownership structures, and the market for corporate control. Review of Financial Studies 5, 181-198.

Klein, P., 2001, The capital gain lock-in effect and equilibrium returns, Journal of Public Economics 71, 355-378.

Landsman, W., and D. Shackelford, 1995, The lock-in effect of capital gains taxes: Evidence from the RJR Nabisco leveraged buyout, National Tax Journal 48, 245-259. Masse, I., R. Hanrahan, and J. Kushner, 1991, The effect of the method of payment on stock returns in Canadian tender offers and merger proposals for both target and bidding firms, Quarterly Journal of Business 30, 102-124.

Moeller, S., F. Schlingemann, and R. Stulz, 2004, Firm size and the gains from acquisitions, Journal of Financial Economics 73, 201-228.

Myers, S., and N. Majluf, 1983, Corporate financing and investment decisions when firms have information that investors do not have, Journal of Financial Economics $13,187-221$.

Raad, E., R. Ryan, and J. Sinkey, 1999. Leverage, ownership structure, and returns to shareholders of target and bidding firms. Quarterly Journal of Business and Economics 38, 37-53.

Schwert, G., 2000, Hostility in takeovers: In the eyes of the beholder? Journal of Finance 55, 2599-2640. 
Stulz, R., 1988, Managerial control of voting rights: Financing policies and the market for corporate control, Journal of Financial Economics 20, 25-54.

Stulz, R., R. Walkling, and M. Song, 1990, The distribution of target ownership and the division of gains in successful takeovers, Journal of Finance 45, 817-833.

Travlos, N., 1987, Corporate takeover bids, methods of payment, and bidding firms' stock returns, Journal of Finance 42, 943-963.

Viard, A., 2000, Dynamic asset pricing effects and incidence of realization-based capital gains taxes, Journal of Monetary Economics 46, 465-488.

Wansley, J., W. Lane, and H. Yang, 1983, Abnormal returns to acquired firms by type of acquisition and method of payment, Financial Management 12, 16-22.

White, H., 1980, A heteroscedasticity consistent covariance matrix estimator and a direct test of heteroscedasticity, Econometrica 48, 817-818. 
Table 1

Sample selection

Takeovers announced for ASX listed companies between 1996 and 2003 are included in the sample. The table identifies reasons for exclusion of takeovers from the final sample.

Takeovers for ASX listed targets announced between 1996 and 2003

Exclusions:

Bidders not listed on Australian Stock Exchange

Price data unavailable to calculate abnormal return around takeover announcement

Target firm does not disclose required information

Offer withdrawn prior to release of target statutory documents

Target firm has no financial information as it is listed in year of takeover 
Table 2

Abnormal returns and capital gains

before and after the introduction of CGT rollover relief

The table presents BHARs for target (Bhartgt) and bidders (Bharbid) over the two month period commencing one month prior to the takeover announcement. Target shareholder capital gains over the two years prior to the takeover are approximated using average share prices (CGPrior) and the indexed share price two years before the takeover announcement (CGIndex). Panels A and B respectively show mean values pre and post introduction of the CGT rollover relief in equity takeovers.

\begin{tabular}{lcccc}
\hline & Cash & Equity & Mixed & Total \\
\hline $\begin{array}{l}\text { Panel A: Pre- rollover } \\
\text { relief }\end{array}$ & & & & \\
Number & 51 & 31 & 20 & 102 \\
Bhartgt & $20.61^{* * *}$ & $7.64^{* * *}$ & $12.05^{* * *}$ & $15.06^{* * *}$ \\
Bharbid & -2.47 & -2.41 & $-4.80^{*}$ & $-2.91^{*}$ \\
CGPrior & -1.44 & $-11.92^{* * *}$ & -2.16 & $-4.70^{* * *}$ \\
CGIndex & 4.79 & -7.65 & -6.14 & -1.12 \\
\hline Panel B: Post- rollover & & & & \\
relief & & & & \\
Number & 50 & 35 & 18 & 103 \\
Bhartgt & $28.78^{* * *}$ & $11.92^{* * *}$ & $25.10^{* * *}$ & $22.39^{* * *}$ \\
Pre- vs post- $t$-test & -1.44 & -0.27 & -1.49 & $-1.84^{*}$ \\
Bharbid & -2.73 & $-8.92^{* *}$ & 1.47 & $-4.09^{* *}$ \\
Pre- vs post- $t$-test & 0.09 & 1.22 & -1.44 & 0.50 \\
CGPrior & 1.28 & -5.14 & 3.71 & -0.01 \\
Pre- vs post- $t$-test & -0.84 & -1.40 & -1.02 & $-1.70^{*}$ \\
CGIndex & -2.12 & $-9.75^{* *}$ & 2.99 & -3.82 \\
Pre- vs post- $t$-test & 1.15 & 0.20 & -1.02 & 0.57 \\
\hline
\end{tabular}

* indicates significance at the .10 level

** indicates significance at the .05 level

*** indicates significance at the .01 level 
Table 3

\section{Variable means across payment method}

This table presents the means of the dependent and independent variables included in the regression models. A univariate test of differences in means across payment methods is also presented. Variable definitions are given in Appendix A.

\begin{tabular}{|c|c|c|c|c|c|c|c|}
\hline & $\begin{array}{c}\text { Cash } \\
(\mathrm{n}=101)\end{array}$ & $\begin{array}{c}\text { Mixed } \\
(\mathrm{n}=38)\end{array}$ & $\begin{array}{c}\text { Equity } \\
(\mathrm{n}=66)\end{array}$ & $\begin{array}{c}\text { Total } \\
(\mathrm{n}=205)\end{array}$ & $\begin{array}{l}\text { Cash v } \\
\text { Equity }\end{array}$ & $\begin{array}{l}\text { Cash v } \\
\text { Mixed }\end{array}$ & $\begin{array}{c}\text { Mixed } \\
\text { v Equity }\end{array}$ \\
\hline $\begin{array}{l}\text { Panel A: Mean for } \\
\text { continuous variables }\end{array}$ & & & & & $t$-test & $t$-test & $t$-test \\
\hline Bhartgt & 24.57 & 18.23 & 10.21 & 18.84 & $3.27 * * *$ & 1.23 & -1.44 \\
\hline Bharbid & -2.45 & -1.83 & -6.85 & -3.70 & 1.47 & -0.24 & 1.47 \\
\hline CGPrior & -0.10 & 0.62 & -8.27 & -2.57 & $2.81 * * *$ & -0.22 & $2.40 * *$ \\
\hline CGIndex & 1.37 & -1.96 & -8.78 & -2.49 & $1.74 *$ & 0.62 & 1.02 \\
\hline TgtInst & 11.20 & 13.78 & 8.72 & 10.89 & 1.18 & -1.22 & $2.15^{* *}$ \\
\hline$N O L$ & 13.91 & 6.30 & 16.53 & 13.33 & -0.47 & $1.92 *$ & $-1.98 * *$ \\
\hline Toehold & 20.39 & 17.46 & 10.40 & 17.11 & $3.46 * * *$ & 0.81 & 1.93* \\
\hline TgtDirown & 12.78 & 6.36 & 12.00 & 11.33 & 0.28 & $2.35^{* *}$ & $-1.99 * *$ \\
\hline TgtMB & 1.82 & 1.30 & 1.84 & 1.71 & -0.05 & 1.57 & -1.12 \\
\hline TgtROE & -8.40 & -1.00 & -17.52 & -9.93 & 0.71 & -1.46 & 1.28 \\
\hline TgtDE & 1.17 & 1.13 & 3.82 & 0.99 & -0.85 & 0.15 & -0.86 \\
\hline TgtCurrent & 3.90 & 1.88 & 6.98 & 4.51 & -1.51 & $1.66^{*}$ & $2.92 * * *$ \\
\hline Bidsize & 19.91 & 19.63 & 18.40 & 19.38 & $4.82 * * *$ & 0.77 & $3.25 * * *$ \\
\hline $\begin{array}{l}\text { Panel B: Mean for } \\
\text { binary variables (\%) }\end{array}$ & & & & & $z$-test & $z$-test & $z$-test \\
\hline Multiple & 28.87 & 25.71 & 17.74 & 24.01 & 1.59 & 0.36 & 0.93 \\
\hline Dirrec & 46.39 & 65.71 & 46.77 & 48.53 & -0.05 & $-1.96 * *$ & $1.80 *$ \\
\hline
\end{tabular}

* indicates significance at the .10 level

** indicates significance at the .05 level

*** indicates significance at the .01 level 


\section{Table 4}

Association between target BHARs, capital gains and payment method

OLS regression testing the impact of target shareholder capital gains and payment method on target firm abnormal returns around a takeover announcement pre and post introduction of capital gains tax rollover relief in December 1999. The dependent variable, Bhartgt, is calculated as the two month BHAR for the target firm commencing one month before the takeover announcement. Other variables are defined in Appendix A. $t$-statistics are presented in parentheses.

\begin{tabular}{|c|c|c|c|c|}
\hline \multirow[b]{2}{*}{ Intercept } & \multicolumn{2}{|c|}{ Before CGT rollover(1) } & \multicolumn{2}{|c|}{$\begin{array}{c}\text { Before and after the change to } \\
\text { CGT rollover (2) }\end{array}$} \\
\hline & $\begin{array}{l}0.2411 \\
(2.31)^{* *}\end{array}$ & $\begin{array}{c}0.2957 \\
(2.91)^{* * *}\end{array}$ & $\begin{array}{l}0.0054 \\
(0.05)\end{array}$ & $\begin{array}{l}0.0338 \\
(0.31)\end{array}$ \\
\hline CGPrior & $\begin{array}{l}-0.0501 \\
(-0.20)\end{array}$ & - & $\begin{array}{c}-0.0036 \\
(-0.01)\end{array}$ & - \\
\hline CGIndex & - & $\begin{array}{c}-0.0564 \\
(-0.48)\end{array}$ & - & $\begin{array}{l}0.0786 \\
(0.71)\end{array}$ \\
\hline Payt & $\begin{array}{l}0.0860 \\
(2.50)^{* *}\end{array}$ & $\begin{array}{l}0.1013 \\
(2.56)^{* *}\end{array}$ & $\begin{array}{l}0.0802 \\
(2.09) * *\end{array}$ & $\begin{array}{l}0.0705 \\
(1.85)^{*}\end{array}$ \\
\hline CG*Payt & $\begin{array}{c}-0.3211 \\
(-0.95)\end{array}$ & $\begin{array}{r}-0.0237 \\
(-0.24)\end{array}$ & $\begin{array}{l}-0.2616 \\
(-0.98)\end{array}$ & $\begin{array}{l}-0.0955 \\
(-0.87)\end{array}$ \\
\hline CG*Payt*Change & - & - & $\begin{array}{c}-0.7747 \\
(-2.14)^{* *}\end{array}$ & $\begin{array}{l}-0.6002 \\
(-1.87)^{*}\end{array}$ \\
\hline CG*Change & - & - & $\begin{array}{l}0.4800 \\
(1.45)\end{array}$ & $\begin{array}{l}0.3086 \\
(1.47)\end{array}$ \\
\hline Change & - & - & $\begin{array}{c}0.0936 \\
(2.60) * * *\end{array}$ & $\begin{array}{c}0.0845 \\
(2.15)^{* *}\end{array}$ \\
\hline TgtInst & $\begin{array}{l}0.0605 \\
(0.43)\end{array}$ & $\begin{array}{l}0.0156 \\
(0.11)\end{array}$ & $\begin{array}{l}0.1634 \\
(1.10)\end{array}$ & $\begin{array}{l}0.1490 \\
(0.97)\end{array}$ \\
\hline$C G^{*}$ TgtInst & $\begin{array}{l}1.1072 \\
(0.69)\end{array}$ & $\begin{array}{l}1.2338 \\
(1.43)\end{array}$ & $\begin{array}{l}-1.0681 \\
(-0.78)\end{array}$ & $\begin{array}{c}-0.6566 \\
(-0.80)\end{array}$ \\
\hline NOL & $\begin{array}{c}-0.0978 \\
(-0.91)\end{array}$ & $\begin{array}{l}-0.1091 \\
(-1.10)\end{array}$ & $\begin{array}{l}-0.0022 \\
(-0.04)\end{array}$ & $\begin{array}{c}-0.0354 \\
(-0.69)\end{array}$ \\
\hline Toehold & $\begin{array}{l}-0.1666 \\
(-1.52)\end{array}$ & $\begin{array}{l}-0.1809 \\
(-1.59)\end{array}$ & $\begin{array}{l}-0.0225 \\
(-0.21)\end{array}$ & $\begin{array}{c}-0.0283 \\
(-0.27)\end{array}$ \\
\hline TgtDirown & $\begin{array}{l}-0.1261 \\
(-1.09)\end{array}$ & $\begin{array}{l}-0.2047 \\
(-1.79)^{*}\end{array}$ & $\begin{array}{l}-0.2380 \\
(-1.87)^{*}\end{array}$ & $\begin{array}{l}0.1886 \\
(1.60)\end{array}$ \\
\hline TgtMB & $\begin{array}{l}-0.0254 \\
(-2.40)^{* *}\end{array}$ & $\begin{array}{c}-0.0352 \\
(-2.95)^{* * *}\end{array}$ & $\begin{array}{l}-0.0148 \\
(-1.90)^{*}\end{array}$ & $\begin{array}{c}-0.0193 \\
(-2.99)^{* * *}\end{array}$ \\
\hline TgtROE & $\begin{array}{c}-0.0171 \\
(-0.19)\end{array}$ & $\begin{array}{c}-0.0430 \\
(-0.51)\end{array}$ & $\begin{array}{l}-0.0386 \\
(-1.81)^{*}\end{array}$ & $\begin{array}{c}-0.0464 \\
(-2.05)^{* *}\end{array}$ \\
\hline TgtDE & $\begin{array}{c}0.0602 \\
(4.54)^{* * *}\end{array}$ & $\begin{array}{c}0.0641 \\
(4.84)^{* * *}\end{array}$ & $\begin{array}{c}0.0359 \\
(2.26)^{* *}\end{array}$ & $\begin{array}{c}0.0413 \\
(2.55)^{* *}\end{array}$ \\
\hline TgtCurrent & $\begin{array}{r}-0.0017 \\
(-0.29)\end{array}$ & $\begin{array}{c}-0.0025 \\
(-0.43)\end{array}$ & $\begin{array}{l}-0.0016 \\
(-0.82)\end{array}$ & $\begin{array}{c}-0.0016 \\
(-0.78)\end{array}$ \\
\hline Multiple & $\begin{array}{l}0.0939 \\
(1.68)^{*}\end{array}$ & $\begin{array}{l}0.0771 \\
(1.36)\end{array}$ & $\begin{array}{l}0.0436 \\
(0.96)\end{array}$ & $\begin{array}{l}0.0440 \\
(0.97)\end{array}$ \\
\hline Dirrec & $\begin{array}{l}0.0056 \\
(0.23)\end{array}$ & $\begin{array}{l}0.0031 \\
(0.07)\end{array}$ & $\begin{array}{l}-0.0695 \\
(-1.86)^{*}\end{array}$ & $\begin{array}{l}-0.0738 \\
(-1.91)^{*}\end{array}$ \\
\hline Bidsize & $\begin{array}{c}-0.0065 \\
(-1.49)\end{array}$ & $\begin{array}{r}-0.0077 \\
(-1.40)\end{array}$ & $\begin{array}{l}0.0036 \\
(0.67)\end{array}$ & $\begin{array}{l}0.0036 \\
(0.65)\end{array}$ \\
\hline F-statistic & $2.01^{* *}$ & $2.09 * *$ & $2.70 * * *$ & $2.50 * * *$ \\
\hline Adjusted $\mathrm{R}^{2}$ & 0.1327 & 0.1421 & 0.1330 & 0.1195 \\
\hline $\mathrm{N}$ & 102 & 102 & 205 & 205 \\
\hline
\end{tabular}

***,** and $*$ indicate significance at the $.01, .05$ and .10 levels, respectively 


\section{Table 5}

Association between bidder BHARs, capital gains and payment method

OLS regression estimated to test the impact of target shareholder capital gains and payment method on acquiring firm abnormal returns around a takeover announcement pre and post introduction of capital gains tax rollover relief in December 1999. The dependent variable, Bharbid, is calculated as the two month BHAR for the bidding firm commencing one month before the takeover announcement. Other variables are defined in Appendix A. t-statistics are presented in parentheses.

\begin{tabular}{|c|c|c|c|c|}
\hline \multirow[b]{2}{*}{ Intercept } & \multicolumn{2}{|c|}{ Before CGT rollover (1) } & \multicolumn{2}{|c|}{$\begin{array}{c}\text { Before and after the change to } \\
\text { CGT rollover (2) }\end{array}$} \\
\hline & $\begin{array}{l}0.2207 \\
(1.17)\end{array}$ & $\begin{array}{l}0.2348 \\
(1.13)\end{array}$ & $\begin{array}{l}0.0100 \\
(0.07)\end{array}$ & $\begin{array}{c}-0.0584 \\
(-0.45)\end{array}$ \\
\hline CGPrior & $\begin{array}{l}0.1460 \\
(0.96)\end{array}$ & - & $\begin{array}{c}0.1874 \\
(1.33)\end{array}$ & - \\
\hline CGIndex & - & $\begin{array}{l}0.0786 \\
(0.97)\end{array}$ & - & $\begin{array}{l}0.0654 \\
(1.00)\end{array}$ \\
\hline Payt & $\begin{array}{c}-0.0009 \\
(-0.03)\end{array}$ & $\begin{array}{l}0.0013 \\
(0.04)\end{array}$ & $\begin{array}{l}0.0168 \\
(0.71)\end{array}$ & $\begin{array}{l}0.0104 \\
(0.45)\end{array}$ \\
\hline$C G^{*}$ Payt & $\begin{array}{c}-0.0963 \\
(-0.57)\end{array}$ & $\begin{array}{l}-0.0704 \\
(-1.06)\end{array}$ & $\begin{array}{l}-0.0699 \\
(-0.42)\end{array}$ & $\begin{array}{l}-0.0600 \\
(-1.06)\end{array}$ \\
\hline CG*Payt*Change & - & - & $\begin{array}{l}-0.3471 \\
(-1.72)^{*}\end{array}$ & $\begin{array}{l}-0.3262 \\
(-2.44)^{* *}\end{array}$ \\
\hline CG*Change & - & - & $\begin{array}{l}0.0980 \\
(0.59)\end{array}$ & $\begin{array}{l}0.1194 \\
(1.35)\end{array}$ \\
\hline Change & - & - & $\begin{array}{l}0.0097 \\
(0.44)\end{array}$ & $\begin{array}{l}0.0136 \\
(0.63)\end{array}$ \\
\hline TgtInst & $\begin{array}{l}0.2947 \\
(1.75)^{*}\end{array}$ & $\begin{array}{l}0.2421 \\
(1.53)\end{array}$ & $\begin{array}{l}0.2667 \\
(2.14)^{* *}\end{array}$ & $\begin{array}{l}0.2721 \\
(2.21)^{* *}\end{array}$ \\
\hline$C G^{*}$ TgtInst & $\begin{array}{l}1.2403 \\
(1.05)\end{array}$ & $\begin{array}{c}0.8861 \\
(1.63)\end{array}$ & $\begin{array}{l}0.4042 \\
(0.48)\end{array}$ & $\begin{array}{l}0.5364 \\
(1.18)\end{array}$ \\
\hline NOL & $\begin{array}{l}0.0400 \\
(0.50)\end{array}$ & $\begin{array}{c}0.0386 \\
(0.50)\end{array}$ & $\begin{array}{c}0.1471 \\
(2.62)^{* * *}\end{array}$ & $\begin{array}{c}0.1478 \\
(2.64) * * *\end{array}$ \\
\hline Toehold & $\begin{array}{l}0.0360 \\
(0.40)\end{array}$ & $\begin{array}{l}0.0410 \\
(0.47)\end{array}$ & $\begin{array}{c}-0.0491 \\
(-0.85)\end{array}$ & $\begin{array}{l}-0.0392 \\
(-0.68)\end{array}$ \\
\hline TgtDirown & $\begin{array}{l}0.0735 \\
(0.75)\end{array}$ & $\begin{array}{l}0.0718 \\
(0.76)\end{array}$ & $\begin{array}{l}-0.0081 \\
(-0.11)\end{array}$ & $\begin{array}{l}-0.0102 \\
(-0.14)\end{array}$ \\
\hline TgtMB & $\begin{array}{c}-0.0198 \\
(-2.49)^{* *}\end{array}$ & $\begin{array}{c}-0.0329 \\
(-3.28) * * *\end{array}$ & $\begin{array}{c}-0.0136 \\
(-3.19) * * *\end{array}$ & $\begin{array}{c}-0.0178 \\
(-3.37)^{* * *}\end{array}$ \\
\hline TgtROE & $\begin{array}{c}-0.0530 \\
(-0.96)\end{array}$ & $\begin{array}{c}-0.0572 \\
(-1.06)\end{array}$ & $\begin{array}{c}0.0012 \\
(0.09)\end{array}$ & $\begin{array}{c}0.0030 \\
(0.22)\end{array}$ \\
\hline TgtDE & $\begin{array}{l}0.0044 \\
(0.56)\end{array}$ & $\begin{array}{c}0.0030 \\
(0.37)\end{array}$ & $\begin{array}{c}0.0217 \\
(2.59)^{* * *}\end{array}$ & $\begin{array}{c}0.0235 \\
(2.68)^{* * *}\end{array}$ \\
\hline TgtCurrent & $\begin{array}{c}-0.0069 \\
(-2.53)^{* *}\end{array}$ & $\begin{array}{c}-0.0071 \\
(-2.92)^{* * *}\end{array}$ & $\begin{array}{l}-0.0020 \\
(-1.68)^{*}\end{array}$ & $\begin{array}{l}-0.0020 \\
(-1.74)^{*}\end{array}$ \\
\hline Multiple & $\begin{array}{l}-0.0234 \\
(-0.73)\end{array}$ & $\begin{array}{c}-0.0263 \\
(-0.79)\end{array}$ & $\begin{array}{c}-0.0008 \\
(-0.03)\end{array}$ & $\begin{array}{c}-0.0008 \\
(-0.04)\end{array}$ \\
\hline Dirrec & $\begin{array}{l}0.0016 \\
(0.05)\end{array}$ & $\begin{array}{l}0.0069 \\
(0.21)\end{array}$ & $\begin{array}{c}0.0196 \\
(0.88)\end{array}$ & $\begin{array}{l}0.0193 \\
(0.88)\end{array}$ \\
\hline Bidsize & $\begin{array}{c}-0.0131 \\
(-1.32)\end{array}$ & $\begin{array}{c}-0.0086 \\
(-0.91)\end{array}$ & $\begin{array}{c}-0.0047 \\
(-0.67)\end{array}$ & $\begin{array}{c}-0.0011 \\
(-0.16)\end{array}$ \\
\hline F-statistic & $1.63 *$ & $1.99 * *$ & $3.00 * * *$ & $3.20 * * *$ \\
\hline Adjusted $\mathrm{R}^{2}$ & 0.0896 & 0.1337 & 0.1561 & 0.1691 \\
\hline $\mathrm{N}$ & 102 & 102 & 205 & 205 \\
\hline
\end{tabular}

***,** and $*$ indicate significance at the $.01, .05$ and .10 levels, respectively 


\section{Table 6}

Association between target BHARs, one year capital gains and payment method

OLS regression testing the impact of target shareholder capital gains over the year prior to the takeover and payment method on target firm abnormal returns around a takeover announcement pre and post introduction of the $50 \%$ capital gains tax discount in September 1999.. The dependent variable, Bhartgt, is calculated as the two month BHAR for the target firm commencing one month before the takeover announcement. Other variables are defined in Appendix A. $t$-statistics are presented in parentheses.

\begin{tabular}{|c|c|c|c|c|}
\hline \multirow[b]{2}{*}{ Intercept } & \multicolumn{2}{|c|}{$\begin{array}{l}\text { Before the introduction } \\
\text { of CGT discount (1) }\end{array}$} & \multicolumn{2}{|c|}{$\begin{array}{l}\text { Before and after the } \\
\text { introduction } \\
\text { of CGT discount (2) }\end{array}$} \\
\hline & $\begin{array}{l}0.2138 \\
(2.07) * *\end{array}$ & $\begin{array}{c}0.2608 \\
(2.59) * *\end{array}$ & $\begin{array}{l}0.0308 \\
(0.28)\end{array}$ & $\begin{array}{l}0.0127 \\
(-0.11)\end{array}$ \\
\hline CGPrior1yr & $\begin{array}{l}-0.0887 \\
(-0.38)\end{array}$ & - & $\begin{array}{l}0.4387 \\
(1.64)\end{array}$ & - \\
\hline CGIndex1yr & - & $\begin{array}{l}-0.1184 \\
(-0.87)\end{array}$ & - & $\begin{array}{l}0.0477 \\
(0.35)\end{array}$ \\
\hline Payt & $\begin{array}{c}0.0938 \\
(2.49) * *\end{array}$ & $\begin{array}{l}0.1096 \\
(2.60)^{* *}\end{array}$ & $\begin{array}{l}0.0760 \\
(1.92)^{*}\end{array}$ & $\begin{array}{c}0.0945 \\
(2.38) * *\end{array}$ \\
\hline$C G^{*}$ Payt & $\begin{array}{l}-0.4979 \\
(-1.36)\end{array}$ & $\begin{array}{c}-0.0114 \\
(-0.08)\end{array}$ & $\begin{array}{l}-0.1743 \\
(-1.37)\end{array}$ & $\begin{array}{l}-0.1560 \\
(-0.97)\end{array}$ \\
\hline CG*Payt ${ }^{*}$ ChangeIdx & - & - & $\begin{array}{l}0.0836 \\
(0.67)\end{array}$ & $\begin{array}{l}-0.1455 \\
(-1.06)\end{array}$ \\
\hline CG*ChangeIdx & - & - & $\begin{array}{c}0.0095 \\
(0.08)\end{array}$ & $\begin{array}{c}0.0139 \\
(0.13)\end{array}$ \\
\hline ChangeIdx & - & - & $\begin{array}{l}0.0587 \\
(1.55)\end{array}$ & $\begin{array}{l}0.0610 \\
(1.58)\end{array}$ \\
\hline TgtInst & $\begin{array}{l}0.0497 \\
(0.30)\end{array}$ & $\begin{array}{c}0.0093 \\
(0.06)\end{array}$ & $\begin{array}{c}0.1475 \\
(0.99)\end{array}$ & $\begin{array}{l}0.1324 \\
(0.86)\end{array}$ \\
\hline CG*TgtInst & $\begin{array}{l}0.5134 \\
(0.41)\end{array}$ & $\begin{array}{l}1.3216 \\
(0.98)\end{array}$ & $\begin{array}{l}-0.4033 \\
(-0.29)\end{array}$ & $\begin{array}{l}-0.4430 \\
(-0.37)\end{array}$ \\
\hline$N O L$ & $\begin{array}{l}-0.0909 \\
(-0.86)\end{array}$ & $\begin{array}{l}-0.1140 \\
(-1.06)\end{array}$ & $\begin{array}{l}0.0143 \\
(0.23)\end{array}$ & $\begin{array}{l}-0.0009 \\
(-0.02)\end{array}$ \\
\hline Toehold & $\begin{array}{l}-0.1256 \\
(-1.01)\end{array}$ & $\begin{array}{l}-0.1549 \\
(-1.20)\end{array}$ & $\begin{array}{l}-0.0122 \\
(-0.12)\end{array}$ & $\begin{array}{l}-0.0305 \\
(-0.29)\end{array}$ \\
\hline TgtDirown & $\begin{array}{l}-0.0918 \\
(-0.82)\end{array}$ & $\begin{array}{l}-0.1518 \\
(-1.28)\end{array}$ & $\begin{array}{l}0.2124 \\
(1.73)^{*}\end{array}$ & $\begin{array}{l}0.1775 \\
(1.39)\end{array}$ \\
\hline TgtMB & $\begin{array}{c}-0.0229 \\
(-2.21)^{* *}\end{array}$ & $\begin{array}{c}-0.0324 \\
(-2.09) * *\end{array}$ & $\begin{array}{l}-0.0181 \\
(-2.44)^{* *}\end{array}$ & $\begin{array}{l}-0.0162 \\
(-1.71)^{*}\end{array}$ \\
\hline TgtROE & $\begin{array}{c}-0.0789 \\
(-0.77)\end{array}$ & $\begin{array}{l}-0.1131 \\
(-1.08)\end{array}$ & $\begin{array}{l}-0.0305 \\
(-1.55)\end{array}$ & $\begin{array}{r}-0.0287 \\
(-1.35)\end{array}$ \\
\hline TgtDE & $\begin{array}{c}0.0550 \\
(4.46)^{* * *}\end{array}$ & $\begin{array}{c}0.0573 \\
(3.87)^{* * *}\end{array}$ & $\begin{array}{c}0.0434 \\
(2.73)^{* * *}\end{array}$ & $\begin{array}{c}0.0455 \\
(2.48) * *\end{array}$ \\
\hline TgtCurrent & $\begin{array}{c}-0.0054 \\
(-0.91)\end{array}$ & $\begin{array}{l}-0.0058 \\
(-1.08)\end{array}$ & $\begin{array}{l}-0.0003 \\
(-0.19)\end{array}$ & $\begin{array}{r}-0.0007 \\
(-0.35)\end{array}$ \\
\hline Multiple & $\begin{array}{l}0.0408 \\
(0.68)\end{array}$ & $\begin{array}{c}0.0155 \\
(0.24)\end{array}$ & $\begin{array}{l}0.0580 \\
(1.27)\end{array}$ & $\begin{array}{l}0.0496 \\
(1.04)\end{array}$ \\
\hline Dirrec & $\begin{array}{c}-0.0185 \\
(-0.36)\end{array}$ & $\begin{array}{c}-0.0112 \\
(-0.22)\end{array}$ & $\begin{array}{c}-0.0770 \\
(-1.97)^{* *}\end{array}$ & $\begin{array}{l}-0.0748 \\
(-1.93)^{*}\end{array}$ \\
\hline Bidsize & $\begin{array}{l}-0.0041 \\
(-1.04)\end{array}$ & $\begin{array}{l}-0.0048 \\
(-1.27)\end{array}$ & $\begin{array}{l}0.0034 \\
(0.62)\end{array}$ & $\begin{array}{l}0.0054 \\
(0.91)\end{array}$ \\
\hline F-statistic & $1.98 * *$ & $1.71^{*}$ & $2.55^{* * *}$ & $1.83 * *$ \\
\hline Adjusted $\mathrm{R}^{2}$ & 0.1436 & 0.1078 & 0.1226 & 0.0695 \\
\hline $\mathrm{N}$ & 92 & 92 & 205 & 205 \\
\hline
\end{tabular}

$* * *, * *$ and $*$ indicate significance at the $.01, .05$ and .10 levels, respectively 


\section{Appendix A}

\section{Description and measurement of variables used in this study}

Bhartgt: buy-hold abnormal return for the target firm calculated for the two month period commencing one month prior to the takeover announcement.

Bharbid: buy-hold abnormal return for the bidder firm calculated for the two month period commencing one month prior to the takeover announcement.

CGPrior: estimate of target shareholder capital gain liability measured by subtracting from the share price twenty days before the takeover announcement the average share price over the prior two years, then multiplied by the highest individual marginal tax rate. This capital gain is then scaled by the average share price over the two year period.

CGPrior1yr: estimate of target shareholder capital gain liability measured by subtracting from the share price twenty days before the takeover announcement the average share price over the prior one year, then multiplied by the highest individual marginal tax rate. This capital gain is then scaled by the average share price over the one year period.

CGIndex: for takeovers before 21 September 1999, target shareholder capital gain liability estimated by subtracting from the share price twenty days before the takeover announcement, the inflation indexed price from two years prior, then multiplied by the highest individual marginal tax rate. For takeovers after 21 September 1999, target shareholder capital gain liability estimated by subtracting from the share price twenty days before the takeover announcement, the price from two years prior, and then multiplied by the highest individual marginal tax rate. This capital gains amount calculated is then scaled by the share price at the beginning of the two year period.

CGIndex1yr: estimate of target shareholder capital gain liability estimated by subtracting from the share price twenty days before the takeover announcement, the price one year prior, then multiplied by the highest individual marginal tax rate. This capital gains amount calculated is then scaled by the share price at the beginning of the one year period. Payt: a binary variable coded as 1 , where the takeover consideration is exclusively cash. $C G^{*}$ Payt: interaction variable between Payt and, respectively, each measure of $C G$. CG*Payt ${ }^{*}$ Change/(Idx): interaction variable between Payt and Change/(Idx) and, in turn, each measure of $C G$.

$C G^{*}$ Change/(Idx): interaction variable between Change/(Idx) and, in turn, each measure of CG.

Change: a binary variable coded as one for takeovers announced after the introduction of capital gains roll-over for equity consideration

ChangeIdx: a binary variable coded as one for takeovers announced after the introduction of 
the $50 \%$ discount of capital gains on investments held for more than 12 months.

TgtInst: institutional ownership in the target firm estimated at the financial year end prior to the takeover announcement.

CG*TgtInst: interaction variable between TgtInst and in turn each measure of CG.

NOL: tax loss carry-forward of the target firm at the financial year end prior to the takeover announcement, multiplied by the applicable corporate tax rate and scaled by market capitalisation at financial year end.

Toehold: the share ownership of the bidder at the date of the takeover announcement disclosed in bidder firm documents lodged with the ASX.

TgtDirown: the percentage holding of target firm directors disclosed in target firm documents lodged with the ASX.

TgtMB: target firm market-to-book ratio calculated at the financial year end prior to the takeover announcement.

TgtROE: target firm return-on-equity calculated at the financial year end prior to the takeover announcement.

TgtDE: target firm debt-to-equity ratio calculated at the financial year end prior to the takeover announcement.

TgtCurrent: target firm current ratio calculated at the financial year end prior to the takeover announcement.

Multiple: a binary variable coded as one if competing takeover offers are announced for the target firm.

Dirrec: a binary variable coded as one, where the initial recommendation of the target board to shareholders is to accept the offer.

Bidsize: the natural logarithm of the market capitalisation of the acquiring firm measured at the financial year end prior to the takeover announcement. 